\title{
Forest management in view of death
}

E. F. BELL

U.S. Forest Service

Pacific Northwest Forest and Range Experiment Station Portland, Oregon

\section{E. F. THOMPSON}

Division of Forestry and Wildlife Resources

Virginia Polytechnic Institute and State University

Blacksburg, Virginio

Death is inevitable, but when it will occur is uncertain. In anticipation of death, many individuals prepare wills, form trusts, etc. There is no reason why this type of planning should not include forest property management for the private, non-corporate forest landowner.

We assume here that the forest landowner's objective is to maximize the present net worth of his forest property over his life expectancy. By using the concepts of probability and expected value, we develop a model for choosing among alternative forest management plans to achieve this objective.

\section{Probability and expected value}

A basic understanding of the two concepts, probability and expected value, is prerequisite to the model developed in the subsequent section. There are two kinds of probability: objective probability and subjective probability. Objective probability may be defined as the relative frequency of occurrences in a long series of trials under a constant cause system. Subjective probability, on the other hand, is related to an individual's confidence or degree of belief.

A life insurance firm may use long term data to develop the probability that persons of various ages will die within one year. This probability distribution indicates the number of deaths, not who will die. From the viewpoint of the life insurance company, the distribution is objective. However, if an individual assumes that the same data apply to his situation, then the distribution should be con-
Les concepts de probabilité et de valeur espérée peuvent être utilisés pour l'évaluation de plusieurs plans d'aménagement forestiers pour le propriétaire de lots boisés, désireux de maximiser la valeur présente nette de sa propriété forestière au cours de sa vie. L'auteur présente un modèle à ce problème utilisant un cas concret puisé dans l'aménagement d'une plantation de pin rouge.

sidered subjective. Some scientists argue against the use of subjective probability for decision making. But these same people, given two alternatives involving a $20 \%$ and a $70 \%$ chance of death respectively would surely choose the former.

The second concept, expected value, is closely related to averages. It is, in fact, a weighted average. The expected value, EV, of a particular alternative with $\mathrm{k}$ consequences can be expressed algebraically as:

$$
E V=\sum_{i=1}^{k} C_{i} \cdot P\left(C_{i}\right)
$$

where $C_{i}$ is the value of the ith consequence which has a probability of occurrence of $P\left(C_{i}\right)$. Expected value is the sum of all consequence values weighted by their probabilities of happening; it can be interpreted as the mean value over the long run. As in the case of probabilities, in a strict or objective sense, alternatives with more favorable expected values can only be considered better when the decision is to be made many times. However, subjectively the alternatives with the higher expected values seem better even though the decision is to be made only once, i.e., "the odds are better".

\section{The model}

The situation we are considering involves a decision among alternative forest management plans when the owner's objective is to maximize his

TABLE 1. Consequences of death at various ages and expected values for various forest management alternatives Probability of death at age $j$ for an individual now $i$ years old

$$
\mathrm{P}\left(\mathrm{D}_{\mathrm{i} \mid \mathrm{i}}\right) \quad \mathrm{P}\left(\mathrm{D}_{\mathrm{i}+1 \mid \mathrm{i}}\right) \quad \mathrm{P}\left(\mathrm{D}_{\mathrm{j} \mid \mathrm{i}}\right) \quad \mathrm{P}\left(\mathrm{D}_{100 \mid \mathrm{i}}\right)
$$

\begin{tabular}{|c|c|c|c|c|c|}
\hline \multirow{2}{*}{$\begin{array}{l}\text { Forest } \\
\text { management } \\
\text { alternative }\end{array}$} & \multirow[b]{2}{*}{ i } & \multicolumn{2}{|c|}{ Consequences } & \multirow[b]{2}{*}{100} & \multirow[b]{2}{*}{$\begin{array}{l}\text { Expected } \\
\text { value }\end{array}$} \\
\hline & & $i+1^{\text {Age }}$ & $\mathbf{j}$ & & \\
\hline 1 & $\mathrm{PNW}_{1, i}$ & $\mathrm{PNW}_{1, i+1 \mid i}$ & $\mathrm{PNW}_{1, i l i}$ & $\mathrm{PNW}_{1,1001 \mathrm{i}}$ & $\mathrm{EV}_{1}$ \\
\hline 2 & $\mathrm{PNW}_{2, \mathrm{i}\} \mathrm{i}}$ & $\mathrm{PNW}_{2, i+1 \mid i}$ & $\mathrm{PNW}_{2, \mathrm{i} / \mathrm{i}}$ & $P N W_{2,100 \mid i}$ & $\mathrm{EV}_{2}$ \\
\hline : & . & . & . & . & . \\
\hline$\dot{\mathrm{m}}$ & $P N W_{m, i \mid i}$ & $P N W_{m, i+1\} i}$ & $\mathrm{PNW}_{\mathrm{m}, \mathrm{j} / \mathrm{s}}$ & $P N W_{m, 100 \mid i}$ & $E \dot{V}_{p t}$ \\
\hline
\end{tabular}

The expected value of forest management alternative $m$ is:

$$
\mathrm{EV}_{\mathrm{m}}=\sum_{\mathrm{j}=\mathrm{i}}^{100}(\mathrm{PNW} \mathrm{m,j| \textrm {i }})\left(\mathrm{P}\left(\mathrm{D}_{\mathrm{i} \mid \mathrm{i}}\right)\right)
$$


forest's present net worth over his life expectancy. Unfortunately, the owner's age at death cannot be known with certainty. But the probability of death occurring at particular ages, over a large number of individuals, is known.

If the forest owner is willing to apply the overall probabilities of death to his own life, an expected value can be calculated for each alternative forest management plan. A convenient way of formulating the problem is depicted in Table 1 . The remainder of this section is concerned with obtaining the data necessary to develop Table 1.

Standard mortality data, a sample of which is given in Table 2, are used to determine the probability of death at age $j$, for a person currently age $i, P\left(D_{j} i_{i}\right)$. The probability that a person just 20 years old will die before he reaches 21 , i.e., $\mathrm{P}\left(\left.\mathrm{D}_{20}\right|_{20}\right)$, is found by dividing the value opposite age 20 in the second column of Table 2 by 1,000. For this example, $P\left(\left.D_{20}\right|_{20}\right)=0.00179$. Therefore, the probability this person will live beyond age 20 is $1-0.00179$, or 0.99821 .

The probability that the same person will not die at 20 but will die while he is $21, P\left(D_{21 \mid 20}\right)$, is the product of the probability that he will not die at age 20 and the probability that he will die at age 21 . That is,

$$
\begin{gathered}
P\left(D_{21} \mid 20\right)=\left(1-P\left(\left.D_{20}\right|_{20}\right)\right)\left(P\left(\left.D_{21}\right|_{21}\right)\right)= \\
(.99821)(.00183)=0.00183
\end{gathered}
$$

Similarly, the value for $P\left(\left.D_{22}\right|_{20}\right)$ is:

$$
\begin{aligned}
& \left(1-P\left(\left.D_{20}\right|_{20}\right)\right)\left(1-P\left(\left.D_{21}\right|_{21}\right)\right)\left(P\left(\left.D_{22}\right|_{22}\right)\right)= \\
& (.99821)(.99817)(.00186)=0.00185
\end{aligned}
$$

In general, the probability that a person will die at age $j$, given that he is now age $i$, is calculated by the formula:

$$
\mathrm{P}\left(\mathrm{D}_{\mathrm{j} \mid \mathrm{i}}\right)=\left[{ }_{\mathrm{k}=\mathrm{i}}^{\mathrm{i}-1} \mathrm{~d}\left(1-\mathrm{P}\left(\mathrm{D}_{\mathrm{k} \mid \mathrm{k}}\right)\right] \mathrm{P}\left(\left.\mathrm{D}_{\mathrm{j}}\right|_{\mathrm{j}}\right)\right.
$$

The values $\left.\mathrm{PNW}_{\mathrm{m}, \mathrm{j}}\right|_{\mathrm{i}}$ (the present net worth of forest management alternative $m$ when death occurs at age $\mathrm{j}$ for an individual now $\mathrm{i}$ years old) are calculated by discounting the forest's liquidation value at age $\mathrm{j}$ and all revenue received during the period from $i$ to $j$ to year $i$. The discounted value of all costs are discounted with the formula:

$$
\mathrm{PV}=-\frac{\mathrm{V}_{\mathrm{t}}}{(1+\mathrm{p})^{\mathrm{t}}}
$$

where: $\mathrm{PV}=$ present value

$$
\begin{aligned}
\mathrm{V}_{\mathrm{t}}= & \text { value of revenue or cost when it oc- } \\
& \text { curs in year }(\mathrm{i}+\mathrm{t}) \\
\mathrm{p}= & \text { appropriate interest rate }
\end{aligned}
$$

The expected value for a particular management plan, $E V_{m}$, as indicated, is a weighted mean value and represents the value believed most likely to result from the mth plan. It is calculated by summing the products of the probability of death $P\left(D_{j} \mid \mathrm{i}\right)$, and present net worth, $P N W_{m, j} \mid i$, for each age that death might occur. In general, the expected value of alternative $\mathrm{m}$ is calculated as follows:

$$
\mathrm{EV}_{\mathrm{na}}=\sum_{\mathrm{i}=\mathrm{i}}^{100}\left(\left.\mathrm{PNW}_{\mathrm{m}, \mathrm{j}}\right|_{\mathrm{i}}\right)\left(\mathrm{P}\left(\mathrm{D}_{\mathrm{j} / \mathrm{i}}\right)\right)
$$

TABLE 2. Annual death rates for various ages expressed as deaths per 1000 population

Age Deaths/1000 Age Deaths/1000 Age Deaths/100

$\begin{array}{llllll}20 & 1.79 & 30 & 2.13 & 40 & 3.53 \\ 21 & 1.83 & 31 & 2.19 & 41 & 3.84 \\ 22 & 1.86 & 32 & 2.25 & 42 & 4.17 \\ 23 & 1.89 & 33 & 2.32 & 43 & 4.53 \\ 24 & 1.91 & 34 & 2.40 & 44 & 4.92 \\ 25 & 1.93 & 35 & 2.51 & 45 & 5.35 \\ 26 & 1.96 & 36 & 2.64 & 46 & 5.83 \\ 27 & 1.99 & 37 & 2.80 & 47 & 6.36 \\ 28 & 2.03 & 38 & 3.01 & 48 & 6.95 \\ 29 & 2.08 & 39 & 3.25 & 49 & 7.60\end{array}$

Developed from Commissioners 1958 Standard Ordinary Mortality Table as cited in Clifford and Sobel (1964:16).

\section{Use of the model}

To show how the model can be used to maximize the owner's present net worth over his life expectancy, a simple example will be developed using data from a plantation management simulator (Bell 1971).

A forest owner, who is currently 50 years old, has a 20-year-old, 100-acre red pine plantation. He perceives three alternative management plans for the plantation.

1/ Low intensity management with no cultural practices, small annual protection expenditures, and harvesting at plantation age 50 followed by planting with no site preparation.

2/ Moderate intensity management. with two thinnings, moderate annual expenditures, and harvesting at plantation age 50 followed by planting with moderate site preparation.

3/ High intensity management with four thinnings, fertilization, pruning, high annual and protection expenditures, and harvesting at plantation age 50 followed by planting with intensive site preparation.

Information representing the three forest management alternatives was used as input to the red pine simulator. The simulator calculated the present net worth annually for the potentially liquidated stand using an $8 \%$ interest rate. The value for the interest rate was based upon the landowner's assumed cost of capital. Samples of the values derived from these calculations are given in Table 3.

The resulting expected values, in terms of present net worth, for each alternative are:

Alternative

$\begin{array}{ll}1 & \$ 43,587 \\ 2 & \$ 53,736 \\ 3 & \$ 50,118\end{array}$

TABLE 3. Red pine plantation liquidation present net worth

\begin{tabular}{rrrrr}
$\begin{array}{c}\text { Owners } \\
\text { age }\end{array}$ & $\begin{array}{c}\text { Plantation } \\
\text { age }\end{array}$ & $\mathbf{1}$ & \multicolumn{3}{c}{ Alternatives } \\
& & & & $\mathbf{3}$ \\
51 & 21 & $\$ 37864.24$ & $\$ 41979.96$ & $\$ 46093.96$ \\
60 & 30 & 72513.50 & 78102.88 & 78951.24 \\
70 & 40 & 86641.75 & 95029.75 & 93428.44 \\
80 & 50 & 87330.00 & 101726.63 & 96524.38 \\
90 & 10 & 86871.00 & 101046.00 & 95623.00 \\
100 & 20 & 86860.00 & 101024.00 & 95590.00 \\
\hline
\end{tabular}


Given the landowner's objective, he should choose alternative 2 , moderate intensity management, since it has the maximum expected value.

\section{Conclusions}

As the above example indicates, the model developed provides a systematic method for choosing among forest management alternatives when the length of the planning period is uncertain. Granted, the model requires one to believe that an outcome with a high probability of occurrence will in fact occur, but this assumption appears valid in view of human response to this type of situation.

Throughout this paper, time of death has been considered the uncertain factor. These is no reason the same model could not be applied in other situations involving different probabilistic variables. Although the current model only allows one probabilistic variable, it could be easily modified to consider more. The realm of application awaits the perceptive reader.

\section{References}

BELL, E. F. 1971. Simulating a silviculture system. Ph.D. Diss. State Univ. New York Col. Forest Syracuse, New York.

CLIFFORD, P. C. and M. A. SOBEL. 1964. Mathematics in action: the role of mathematics in life insurance. Institute of Life Insurance, New York.

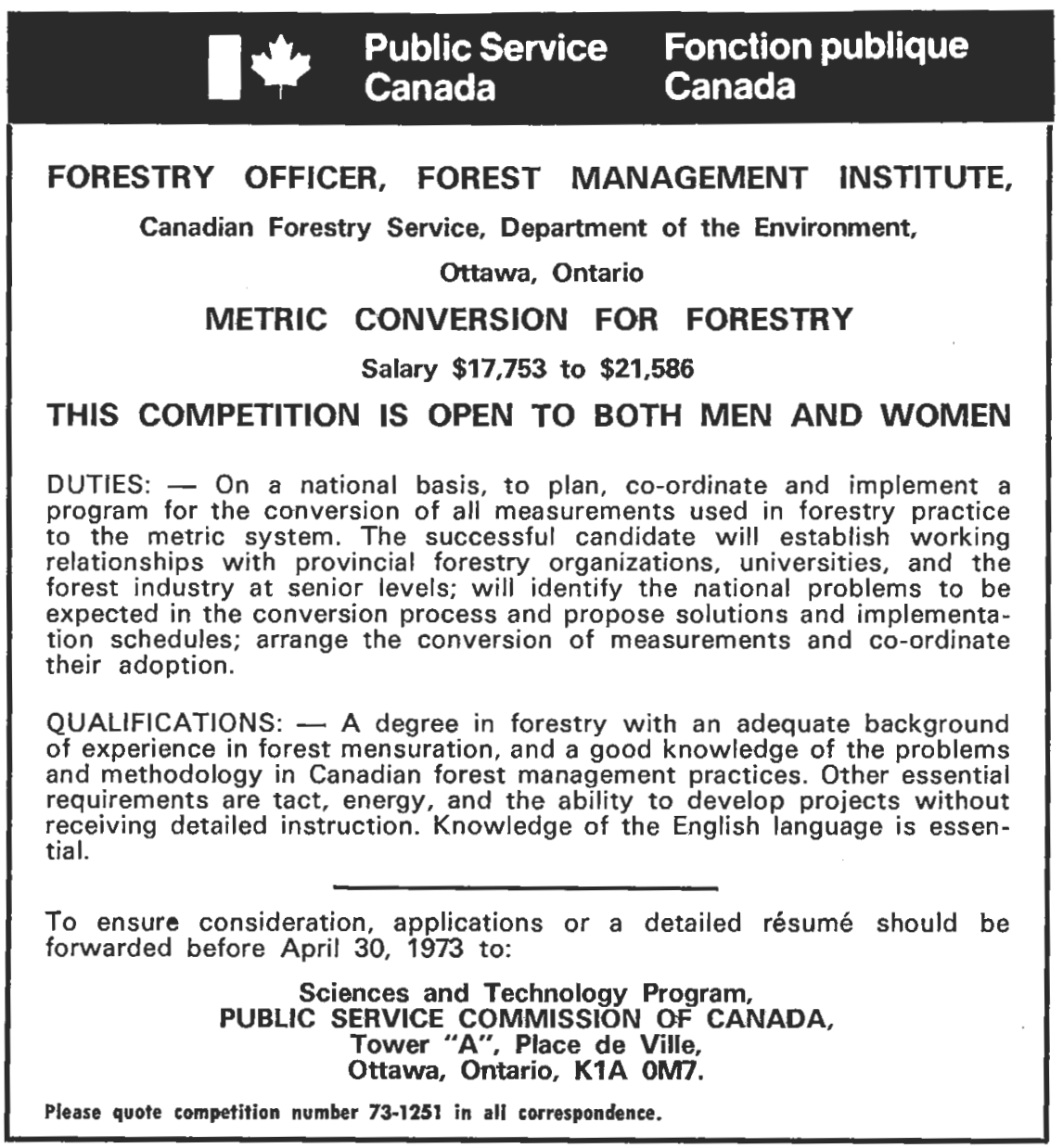

